\title{
Contribution to the mayflies (Insecta, Ephemeroptera) of Israel and the Palestinian Authority
}

\author{
Zohar Yanai $^{1,2}$, Michel Sartori ${ }^{1,2}$, Jean-Luc Gattolliat ${ }^{1,2}$
}

1 Musée Cantonal de Zoologie, Palais de Rumine, 1015 Lausanne, Switzerland. 2 Department of Ecology and Evolution, Biophore, University of Lausanne, 1015 Lausanne, Switzerland.

Corresponding author: Zohar Yanai, yanai.zohar@gmail.com

\begin{abstract}
We here list four unreported mayfly species from Israel and the Palestinian Authority: Cloeon vanharteni Gattolliat \& Sartori, 2008, Cheleocloeon soldani Gattolliat \& Sartori, 2008, Oligoneuriella orontensis Koch, 1980 and Prosopistoma oronti Alouf, 1977. They are reported, morphologically distinguished from other local relatives, and sequenced for their mitochondrial COI barcoding segment. Two species, $C$. vanharteni and Ch. soldani, are known from the Arabian Peninsula, while $O$. orontensis and $P$. oronti are Levantine (with wide or more restricted ranges), emphasizing the importance of the Jordan River catchment as a biogeographic meeting-point.
\end{abstract}

\section{Keywords}

Biogeography, Levant, new record

Academic editor: Inês Corrêa Gonçalves | Received 28 October 2019 | Accepted 11 February 2020 | Published 6 March 2020

Citation: Yanai Z, Sartori M, Gattolliat J-L (2020) Contribution to the mayflies (Insecta, Ephemeroptera) of Israel and the Palestinian Authority. Check List 16 (2): 229-236. https://doi.org/10.15560/16.2.229

\section{Introduction}

Research of mayfly (order Ephemeroptera) diversity in Israel and the Palestinian Authority was pioneered by Matzliah Samocha, who was the first to prepare an inventory of the local species and attempted to identify them. He finished his research in 1972, but never published his findings; they partially became publicly available thanks to Demoulin (1973), Malzacher (1992), and Sartori (1992). These European experts clarified the local species belonging to the families Heptageniidae, Caenidae, Leptophlebiidae, Ephemerellidae, and Palingeniidae. While species of Prosopistomatidae and Oligoneuriidae in Israel are well known by local limnologists and entomologists, they are largely unreported to the international community; they have been anecdotally mentioned by Por et al. (1986) and Dimentman et al. (1992), and there are a few records in grey literature, such as technical reports or Masters Theses. These publications remain mostly unknown to the scientific community, as many of them have been issued in Hebrew and for internal use of local authorities. The rich family Baetidae was recently treated by Yanai et al. (2018) including the description of four new Baetis Leach species, and work continues (Yanai et al. in press). Other families are also being revisited and have resulted in a recently established heptageniid genus (Yanai et al. 2017).

We document records of four mayfly species, newly reported from the study area. We include information on their known distribution, diagnostic morphological characters of their nymphs compared to other similar species locally, and information obtained from their COI sequences. 


\section{Methods}

Collection, identification, and documentation of the newly reported species result from an ongoing study of the local mayfly fauna which has been conducted since 2014. This study includes thorough field excursions led mainly by the first author as part of his PhD. These excursions covered a great majority of freshwaters in Israel and the Palestinian Authority (Fig. 1). Collecting in protected areas was done under collecting permits 40223 , 40720, 41168, 41547, and 41897 from Israel's Nature and Parks Authority. Specimens were collected using a sampling net and transferred to the lab in ethanol. Habitats were characterized and water parameters, such as conductivity, $\mathrm{pH}$, and temperature, were taken in the field using standard measuring devices (e.g. Eutech PCSTestr 35). No identification keys for the regional fauna are currently available. Thus, material was identified based on the original descriptions (for Baetidae: Gattolliat and Sartori 2008; Oligoneuriidae: Koch 1980; Prosopistomatidae: Alouf 1977). Subsequently, the specimens were morphologically compared to similar species in the rich collection of Middle-Eastern mayflies stored in Lausanne.

Examined material is housed in Steinhardt Museum of Natural History (SMNH) in Tel-Aviv University,

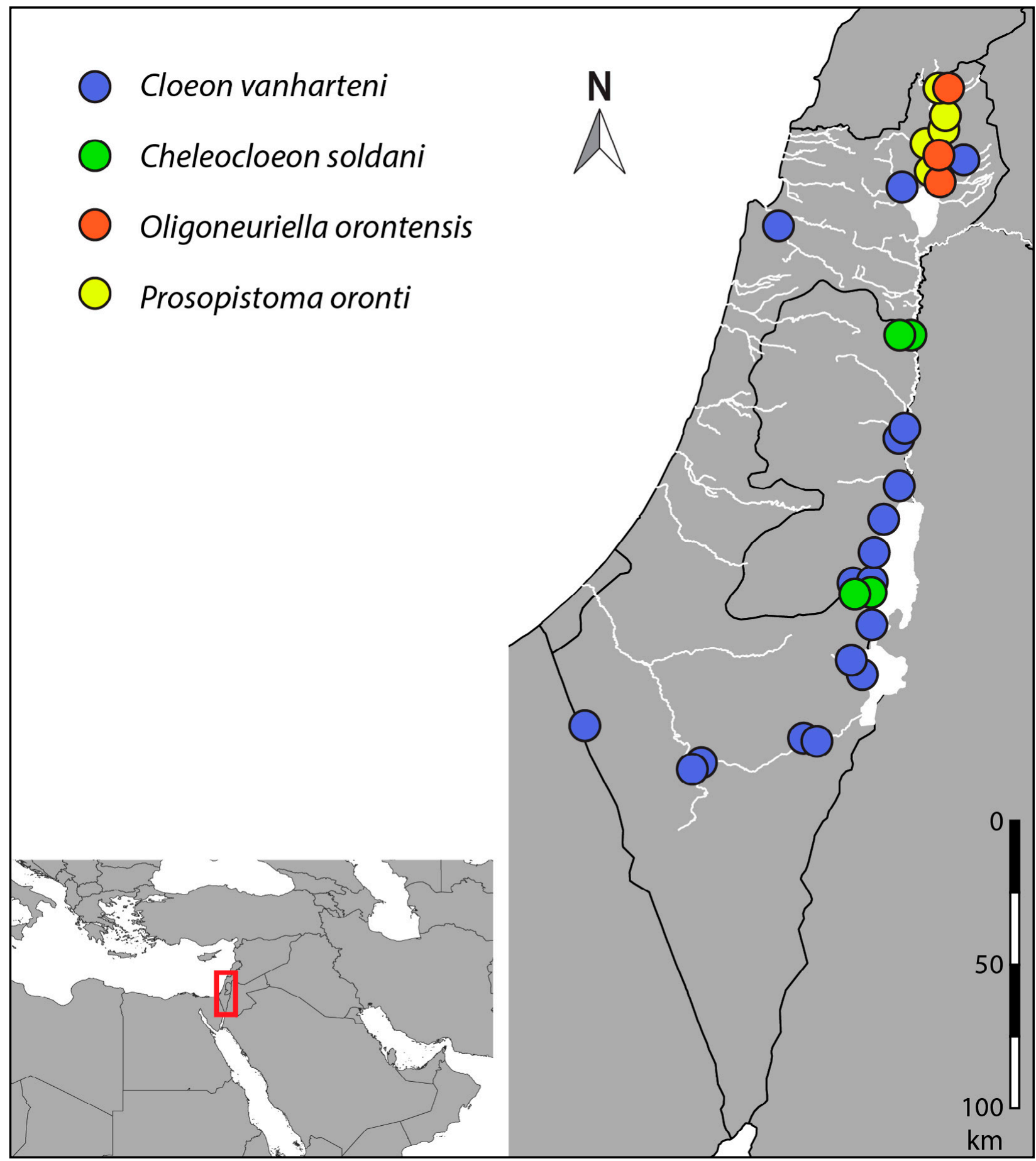

Figure 1. Occurrence of the newly reported species in Israel and the Palestinian Authority. Map shows main watercourses. 
Israel, and in the Museum of Zoology in Lausanne (MZL), Switzerland. The material contains nymphs (N),

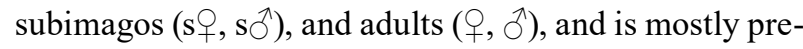
served in ethanol, but in some cases, it is mounted on microscope slides or pinned.

The mitochondrial cytochrome $c$ oxidase subunit I barcoding segment (COI) was sequenced for representatives of each species. We used the primers HCO2198 and LCO1490 (Folmer et al. 1994) and followed the extraction, amplification, and sequencing protocols outlined by Yanai et al. (2018). Sequences were uploaded to GenBank (see accession numbers in Table 1) and BLASTed in order to find the closest match available in GenBank. Molecular analyses were conducted in MEGA7 (Kumar et al. 2015). We used Kimura 2-parameter (K2P) to calculate genetic distances between individual sequences.

\section{Results}

Baetidae

Cloeon vanharteni Gattolliat \& Sartori, 2008

="Cloeon L50"?: Samocha 1972 .

=Cloeon sp.: Hirshberg and Ben-Ami 2019.

Figure 2A

Material examined. ISRAEL • 2ᄋ; Newe Zohar; $31.1482^{\circ} \mathrm{N}, 035.3699^{\circ} \mathrm{E}$; $-384 \mathrm{~m}$ alt. ; 9 Apr. 2014; O. Shamis \& Y. Baar leg. • 2O; same locality; 9 Apr. 2014; N. Galii \& K. Kilimaher leg. • 2ᄋ; same locality; 7 Dec. 2015; N. Keidar leg. • 1s §’; same locality; 29 Dec.2015; Z. Yanai leg. • 3; same locality; 9 Feb. 2016; N. Keidar leg. • 20o; same locality; 1 Mar. 2016; Z. Yanai \& N. Keidar leg. • 6; same locality; 11 Apr. 2016; Z. Yanai leg. • 19, 1ð’; same locality; 1 Feb. 2016; N. Keidar \& N. Bonda leg. - $6 \mathrm{~N}, 1 \mathrm{~s}{ }^{\widehat{\gamma}}$; Boqeq Stream; $31.1970^{\circ} \mathrm{N}$, $035.3488^{\circ} \mathrm{E}$; $-230 \mathrm{~m}$ alt. ; 24 Jun. 2014; Z. Yanai leg. • 1N; same locality; 9 Dec. 2015; Y. Hershkovitz \& T. Esh-

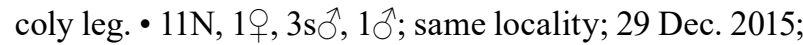
Z. Yanai leg.; GenBank: MN640433 • 27N; same locality; 4 Apr. 2016; Y. Hershkovitz leg. • 20N; same locality; 9 May 2016; Z. Yanai leg. • 6N; same locality; 6 Mar. 2017; Z. Yanai \& J.-L. Gattolliat leg. • 4N; same locality; 19 Apr. 2017; Y. Hershkovitz \& T. Eshcoly leg. • 2N; Dawid Stream; $31.4687^{\circ} \mathrm{N}, 035.3927^{\circ} \mathrm{E} ;-348 \mathrm{~m}$ alt. ; 24 Jun. 2014; Z. Yanai leg. • 4N; same locality; 5 Apr. 2016; Y. Hershkovitz leg. • 1N, 1s $\delta^{\hat{\gamma}}$; Arugot Stream; $31.4561^{\circ} \mathrm{N}$, $035.3773^{\circ} \mathrm{E}$; $-320 \mathrm{~m}$ alt. ; 25 Jun. 2014; Z. Yanai leg. • $7 \mathrm{~N}$; ; Kahal, rock pools; $32.8850^{\circ} \mathrm{N}, 35.5115^{\circ} \mathrm{E} ; 54 \mathrm{~m}$ alt.; 7 Dec. 2014; Z. Yanai leg. • 10N, 26ㅇ, 14 $\overbrace{}^{\text {; }}$ Mizlaot Stream, rock pools; $30.9219^{\circ} \mathrm{N}, 035.1737^{\circ} \mathrm{E} ; 138$ m alt.; 19 Feb. 2016; Z. Yanai leg. - 124N; Zin Stream; $30.9044^{\circ} \mathrm{N}, 035.1857^{\circ} \mathrm{E}$; $-52 \mathrm{~m}$ alt.; 19 Feb. 2016; Z. Yanai leg.; GenBank: MN958846 - 13N; 'En Avedat; $30.8223^{\circ} \mathrm{N}, 034.7640^{\circ} \mathrm{E} ; 494 \mathrm{~m}$ alt.; 7 Apr. 2016; Z. Yanai leg.; GenBank: MN958845 • 1N; same locality; 20

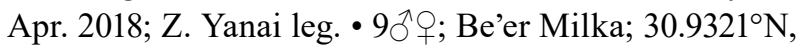
034.4078 ${ }^{\circ}$ E; $236 \mathrm{~m}$ alt.; 30 Jan. 2017; G. Sinaiko \& Y. Itescu leg. • PALESTINIAN AUTHORITY • 20N; Metzoke Dragot, sinkholes; $31.5894^{\circ} \mathrm{N}, 035.4099^{\circ} \mathrm{E} ;-415 \mathrm{~m}$ alt.; i-iii.2015; O. Hirshberg leg. • 30N; 'Einot Tzuqim, sinkholes; $31.7170^{\circ} \mathrm{N}, 035.4544^{\circ} \mathrm{E}$; $-396 \mathrm{~m}$ alt.; i-iii.2015; O. Hirshberg leg. - 4N; Al Ahmar Stream, seasonal reservoir nearby; $31.9902^{\circ} \mathrm{N}, 035.5003^{\circ} \mathrm{E} ;-329 \mathrm{~m}$ alt.; 24 Mar. 2016; E. Elron leg. • 10N; Al Ahmar Stream; $32.0255^{\circ} \mathrm{N}$, $035.5210^{\circ} \mathrm{E}$; $-366 \mathrm{~m}$ alt.; 31 Mar. 2016; E. Elron leg. • 1§ं; Dir Hijla Monastery; $31.8205^{\circ} \mathrm{N}, 035.5018^{\circ} \mathrm{E} ;-324$ m alt.; 26 May 2016; G. Sinaiko leg.

Distribution. This species was originally described from the UAE (Gattolliat and Sartori 2008) and subsequently only reported from a single locality in Jordan (Alhejoj et al. 2020). In Israel and the Palestinian Authority, C. vanharteni was collected mainly in arid and semiarid areas, like the Jordan Valley (in vicinity to Jordan River), the Dead Sea area, and the central Negev Desert. It is also the most abundant mayfly to colonize newly formed sinkholes in the vicinity of the Dead Sea (Hirshberg and Ben-Ami 2019). In many of these localities it was the dominant, or even the sole, mayfly species. A few sporadic individuals were collected in remote sites of a different nature, probably illuminating the high dispersal capacity of the species; however, these sites most likely do not have any sustainable populations. Samocha (1972) mentioned four potential species of Cloeon Leach at the nymphal stage. "Cloeon L50" seems to best correspond to C. vanharteni, as its first gill has upper and lower lamellae, the labial palp is relatively slender, the canines of the right mandible are slender and cleave in two sets, and the claws are long and slender. Bauernfeind and Soldán (2012) reported Cloeon saharense Soldàn \& Thomas, 1983 from Israel, but this is almost certainly a wrong identification, probably of $C$. vanharteni. Both species share some characters, like unmarked female wings and long nymph claws.

Identification. Compared to other local Cloeon species, its nymph can be identified by having relatively small body with large gill lamellae and extremely long claws. The female adult is the only Cloeon from this area without any distinguishable wing pattern (Gattolliat and Sartori 2008).

Table 1. Availability of $\mathrm{COI}$ sequences of the newly reported species, with intraspecific variation and closest available GenBank entries.

\begin{tabular}{llll}
\hline Species & GenBank accession number(s) & Intraspecific similarity (\% of identity) & Closest sequence available in GenBank (\% of identity) \\
\hline $\begin{array}{l}\text { Cloeon vanharteni } \\
\text { Cheleocloeon soldani }\end{array}$ & MN640433, MN958845, MN958846 & $97.8-100.0 \%$ & Procloeon sp., KR677131 (82.2\%) \\
& MN958839 & - & $\begin{array}{l}\text { C. soldani (Saudi Arabia), HG935111 (98.0\%) } \\
\text { Ch. soldani (Jordan), MN944098 (99.4\%) }\end{array}$ \\
Oligoneuriella orontensis & MN958842, MN958843, MN958844 & $99.9-100.0 \%$ & Oligoneuriella rhenana, KY262278 (84.4\%) \\
Prosopistoma oronti & MN958840, MN958841 & $99.9 \%$ & Prosopistoma annamense, MK285323 (82.9\%) \\
\hline
\end{tabular}



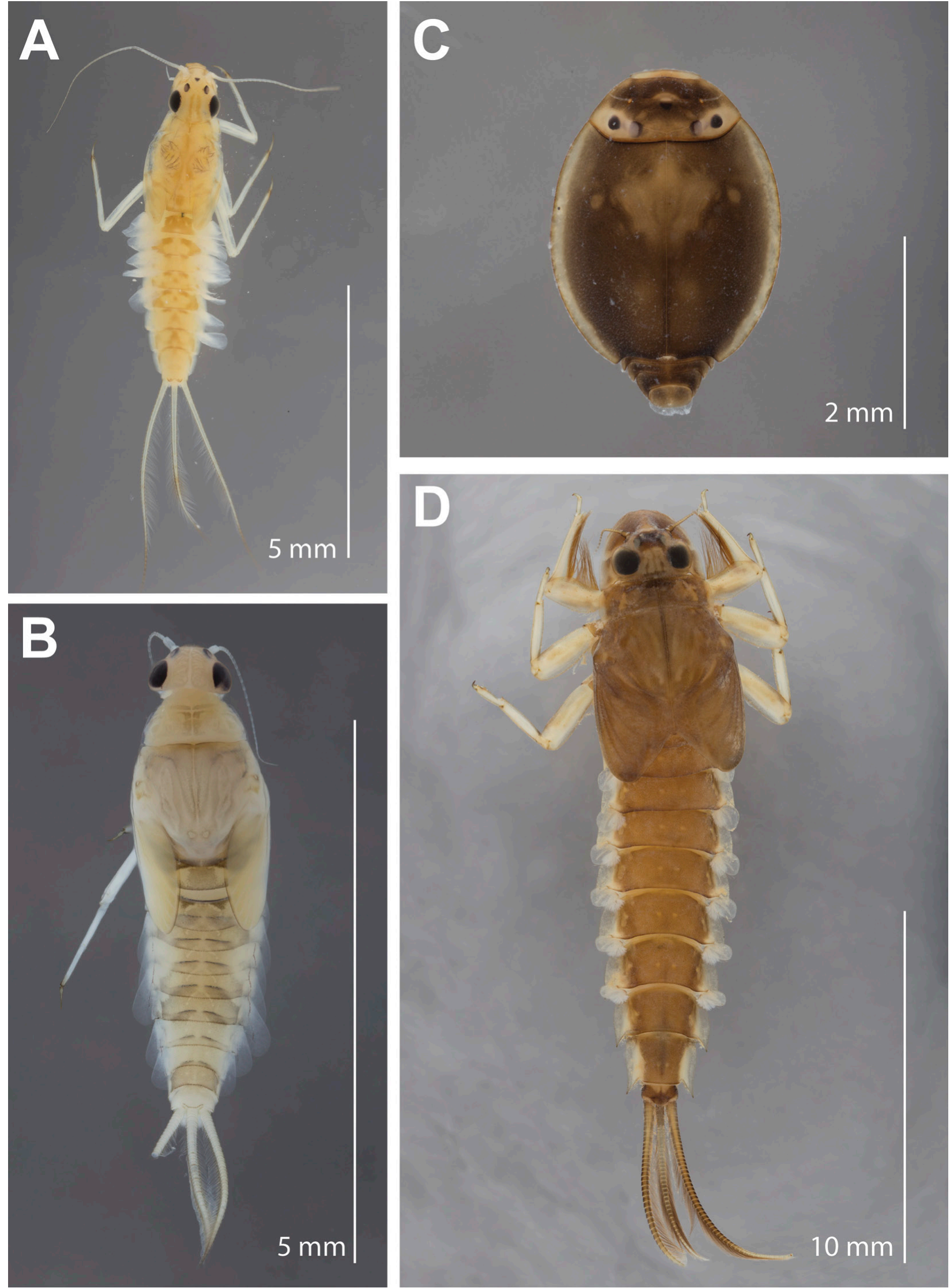

Figure 2. New mayflies recorded from Israel and the Palestinian Authority, nymphs, habitus. A. Cloeon vanharteni. B. Cheleocloeon soldani. C. Prosopistoma oronti. D. Oligoneuriella orontensis. 
Cheleocloeon soldani Gattolliat \& Sartori, 2008 Figure 2B

="Baetis L56": Samocha 1972 : 46, pl. XIX, figs 11-22

Material examined. ISRAEL - 1N; Arugot Stream; $31.4561^{\circ} \mathrm{N}, 035.3773^{\circ} \mathrm{E}$; $-320 \mathrm{~m}$ alt.; 30 Jan. 2017; Z. Yanai \& K. Tamar leg. • 3N; same locality; 7 Mar. 2017; Z. Yanai \& J.-L. Gattolliat leg. • 59N; same locality; 29 Mar. 2019; Z. Yanai leg.; GenBank: MN958839 • PALESTINIAN AUTHORITY • 6N; Milha Stream, near $\operatorname{road} 90 ; 32.3617^{\circ} \mathrm{N}, 035.5293^{\circ} \mathrm{E} ;-223 \mathrm{~m}$ alt.; 24 Mar. 2016; E. Elron leg.

Distribution. The species was reported so far from the UAE (original description by Gattolliat and Sartori 2008), Saudi Arabia (Salles et al. 2014), and Jordan (Alhejoj et al. 2020); it is clearly a desert species. In Israel and the Palestinian Authority, Ch. soldani is now reported from similar habitats in tributaries of the Dead Sea and Lower Jordan River (Fig. 1). While in southern Saudi Arabia, it is very common and abundant (Gattolliat unpublished data), in the southern Levant it seems much rarer, perhaps because it is near the edge of its geographical range.

Identification. As the only representative of the genus in the study area, it is easily recognizable among the local Baetidae by the combination of the following characters: single-lamellae gills, hindwings present in male and absent in female, rows of needle-like spines on distal margins of terga, long claws with two rows of minute teeth, and labial palp with a long, triangular distomedial projection, paracercus as long as cerci and absence of lateral spines on abdomen (Gattolliat and Sartori 2008). It has typical Cloeonini characters (Kluge and Novikova 1992), including rows of needle-like spines on the distal margins of its terga and long claws with two rows of minute teeth. However, it possesses gills with single lamellae. It can be easily identified by the labial palp, which has a long, triangular, distomedial projection. Hindwings present in male and absent in female.

Prosopistomatidae

\section{Prosopistoma oronti Alouf, 1977}

=Prosopistoma yigali nomen nudum; Prosopistoma $\mathrm{sp}$.: Samocha 1972 : 56-58, pl. XXVI, figs 1-11.

=Prosopistoma oront $\mathrm{i}$ : Por et al. 1986 .

=Prosopistoma phoenicium: Degani et al. 1992.

=Prosopistoma oronti: Dimentman et al. 1992.

Figure 2C

Material examined. ISRAEL - 2N; Gilbon Stream, downstream 'En Gilbon; $33.0408^{\circ} \mathrm{N}, 035.6412^{\circ} \mathrm{E} ; 110 \mathrm{~m}$ alt.; 5 May 1990; M. Sartori leg. - 3N; same locality; 15 Jul. 2014; Z. Yanai leg. • 1N; Jordan River, Ateret Fortress; $33.0032^{\circ} \mathrm{N}, 035.6286^{\circ} \mathrm{E}$; $63 \mathrm{~m}$ alt.; 7 May $1990 ; \mathrm{H}$. Glassmann \& M. Sartori leg. • 1N; same locality; 7 May 1991; H. Glassmann \& M. Sartori leg. • 3N; same locality; 8 Dec. 2014; Z. Yanai leg. • 1N; same locality; 27 Mar. 2019; Z. Yanai leg. • 5N; Jordan River, haDodot Bridge; $32.9318^{\circ} \mathrm{N}, 035.6226^{\circ} \mathrm{E} ;-161 \mathrm{~m}$ alt.; 7 May 1990;
H. Glassmann \& M. Sartori leg. • 5N; same locality; 17 Jun. 2015; Y. Hershkovitz \& T. Eshcoly leg. • 1N; same locality; 29 Jul. 2015; Z. Yanai leg. • 20N; same locality; 11 May 2016; Z. Yanai \& N. Dorchin leg. • 2N; Senir (Hasbani) Stream, upstream Ma'ayan Barukh Bridge; $33.2308^{\circ} \mathrm{N}, 035.6209^{\circ} \mathrm{E} ; 119 \mathrm{~m}$ alt.; 10 May 1990; A. Reuven \& M. Sartori leg. - 1N; Jordan River, Benot Yaaqov Bridge; $33.0116^{\circ} \mathrm{N}, 35.6284^{\circ} \mathrm{E} ; 76 \mathrm{~m}$ alt.; 7 May 1991; H. Glassmann \& M. Sartori leg. • 1N; Jordan River, Ariq (Baley) Bridge; $32.9026^{\circ} \mathrm{N}, 035.6149^{\circ} \mathrm{E} ;-206 \mathrm{~m}$ alt.; 7 May 1991; H. Glassmann \& M. Sartori leg. • 2N; Jordan River, Kefar haNassi; $32.9788^{\circ} \mathrm{N}, 035.6261^{\circ} \mathrm{E} ; 10 \mathrm{~m}$ alt.; 7 May 1991; H. Glassmann \& M. Sartori leg. • 2N; Senir (Hasbani) Stream, downstream 'En Barukh; $33.2253^{\circ} \mathrm{N}$, 035.6152 ${ }^{\circ} \mathrm{E}$; $103 \mathrm{~m}$ alt.; 10 May 1991; A. Reuven \& M. Sartori leg. • 7N; 'En Divsha; 33.0901 ${ }^{\circ} \mathrm{N}, 035.6483^{\circ} \mathrm{E}$; $150 \mathrm{~m}$ alt.; 26 Mar. 2014; Z. Yanai leg. • 1N; same locality; 10 Jun. 2014; Z. Yanai leg. • 1N; same locality; 11 May 2015; Y. Hershkovitz \& T. Eshcoly leg. • 2N; same locality; 6 Nov. 2015; Z. Yanai \& S. Cohen leg. • 11N; same locality; 11 May 2016; Z. Yanai \& N. Dorchin leg. • 4N; 'En Maymon; 33.1124 N, 035.6604 E; 290 m alt.; 22 Jun. 2014; Z. Yanai leg. - 2N; same locality; 4 Apr. 2016; Z. Yanai leg. • 1N; same locality; 26 Mar. 2019; Z. Yanai leg. - 2N; 'En Tina; $33.0783^{\circ} \mathrm{N}, 035.6439^{\circ} \mathrm{E}$; $72 \mathrm{~m}$ alt.; $15 \mathrm{Jul}$. 2014; Z. Yanai leg. - 1N; same locality; 6 Dec. 2015; Z. Yanai \& S. Cohen leg. • 13N; same locality; 16 May 2016; Z. Yanai \& A. Charvet leg. • 11N; same locality; 10 Mar. 2017; Z. Yanai \& J.-L. Gattolliat leg. - 2N; same locality; 13 Apr. 2018; Z. Yanai leg. • 5N; same locality; 27 Mar. 2019; Z. Yanai leg.; GenBank: MN958840, MN958841.

Distribution. Alouf (1977) described two species of the genus from Lebanon, $P$. phoenicium and $P$. oronti (the two species were synonymized under the latter by Thomas et al. (1988)). Koch (1988) reported the species from Syria. The proposed specimens of $P$. oronti from Iraq (Bauernfeind and Soldán 2012) have proven to be $P$. helenae Bojková \& Soldán, 2015. In Israel, this remarkable species is reported from northern Israel, where it can be found in small Golan streams and, more rarely, in the Upper Jordan River. It was first collected in Israel by Samocha (1972) and reported as "P. yigali", a nomen nudum, as it was never described. The species was later also briefly mentioned from Israel by Por et al. (1986), Degani et al. (1992), and Dimentman et al. (1992). It appears that the subpopulations in Senir (Hasbani) and Hermon (Banyas) streams (sampled by Samocha 1972) have declined, as the species has not been collected in these well-sampled streams since 1991 (see Material examined).

Identification. The nymphs of $P$. oronti display the unique morphology of the genus (i.e. clear hemispheric structure; Fig. 2C), and this species, as the sole representative of its genus in Israel, is impossible to confuse with any other local species. Adults of the species remain unknown but, like all its congeners, are expected to have forewings with no crossveins. 
Oligoneuriidae

Oligoneuriella orontensis Koch, 1980

="Oligoneuriella sp. n. O. rhenana": Samocha (1972), 51, pl. XXIII, figs 1-9; pl. XXIV, figs 1-8

=Oligoneuriella orontensis: Koch 1988.

= Oligoneuriella orontensis: Por et al. 1986.

=Oligoneuriella orontensis: Degani et al. 1992.

=Oligoneuriella orontensis: Dimentman et al. 1992.

Figure 2D

Material examined. ISRAEL • $1 \mathrm{~N}$; Jordan River, Ateret Fortress; $33.0032^{\circ} \mathrm{N}, 035.6286^{\circ} \mathrm{E}$; $63 \mathrm{~m}$ alt.; 7 May 1990 ; H. Glassmann \& M. Sartori leg. • 1N; same locality; 7 May 1991; H. Glassmann \& M. Sartori leg. • 5N; same locality; 8 Dec. 2014; Z. Yanai leg. • 15N, $3{ }^{3}$; same locality; 29 Oct. 2015; Z. Yanai \& Y. Brenner leg. •14N; same locality; 16 May 2016; Z. Yanai \& A. Charvet leg. $・ 8 \mathrm{~N}$; same locality; 2 Jun. 2016; Y. Hershkovitz \& T. Eshcoly leg. • 3N; same locality; 11 Mar. 2017; Z. Yanai \& J.-L. Gattolliat leg.; GenBank: MN958842 • 4N; same locality; 27 Mar. 2019; Z. Yanai leg.; GenBank: MN958843, MN958844 - 2N; Dan Stream, st. 6; $33.1320^{\circ} \mathrm{N}$, $035.3845^{\circ} \mathrm{E} ; 120 \mathrm{~m}$ alt.; 10 May 1990; A. Reuven \& M. Sartori leg. - 4N; Senir (Hasbani) Stream, upstream Ma'ayan Barukh Bridge; $33.2253^{\circ} \mathrm{N}, 035.6152^{\circ} \mathrm{E} ; 103$ m alt.; 10 May 1990; A. Reuven \& M. Sartori leg. • 1N; same locality; 10 May 1991; A. Reuven \& M. Sartori leg. - 2N; Senir (Hasbani) Stream, downstream 'En Barukh; $33.2308^{\circ} \mathrm{N}, 035.6209^{\circ} \mathrm{E} ; 119 \mathrm{~m}$ alt.; 10 May 1990; A. Reuven \& M. Sartori leg. • 2s + , $1 \delta^{\Uparrow}$; same locality; $25 \mathrm{Jul}$.

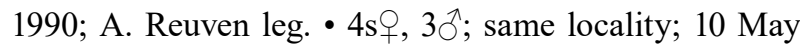
1991; A. Reuven \& M. Sartori leg. • 4N; Hermon (Banyas) Stream, Kefar Szold; $33.1301^{\circ} \mathrm{N}, 035.3832^{\circ} \mathrm{E} ; 100 \mathrm{~m}$ alt.; 8 May 1991; A. Reuven \& M. Sartori leg. • 1N; Jordan River, haDodot Bridge; $32.9318^{\circ} \mathrm{N}, 035.6226^{\circ} \mathrm{E} ;-161$ m alt.; 29 Jul. 2015; Y. Hershkovitz \& T. Eshcoly leg. • 2N; Jordan River, Park haYarden; $32.9091^{\circ} \mathrm{N}, 35.6235^{\circ} \mathrm{E}$; -203 m alt.; 2 Jun. 2016; Y. Hershkovitz \& T. Eshcoly leg.

Distribution. The species was originally described from Turkey by Koch (1980). It was later reported from Lebanon and Syria, partially based on material collected in the 1950s (Koch 1988). In Israel, Samocha (1972) mentioned in his thesis "Oligoneuriella sp." and compared it to $O$. rhenana Imhoff, 1852, indicating some morphological differences. Koch (1988) was confident that it was in fact $O$. orontensis; he was correct to assume this, but he based his observation solely on Samocha's (1972) illustrations and did not personally examine material from Israel. The species was also mentioned from Israel by Por et al. (1986), Degani et al. (1992), and Dimentman et al. (1992). We find it important to officially report $O$. orontensis from Israel, based on recent collecting and examination. In Israel it is currently known from a segment of the Upper Jordan River (mainly around Ateret Fortress). However, until the early 1990s, nymphs and adults were also found in tributaries of this river, as can be seen in the examined material. This fits the older literature, like Samocha (1972) and Por et al. (1986) (later cited also by Dimentman et al. 1992), who only reported the species from the tributaries of the Jordan River.

Identification. The nymph is easily distinguishable from other local mayflies, as it is considerably larger and bears protuberances at the base of the head, and forelegs with rows of long, feathery setae on femur and tibia. The adult is identified by having only an extremely reduced number of paired longitudinal veins in forewings.

\section{Discussion}

The newly reported populations were sequenced for their barcoding region of the mitochondrial cytochrome $c$ oxidase barcoding segment (COI). This serves the purpose of verifying the species identification against available sequences in the case of Ch. soldani, as well as contributing to the construction of a regional mayfly $\mathrm{COI}$ library. Each newly obtained sequence was BLASTed in order to find the closest GenBank entry (Table 1). Except for Ch. soldani, which showed $98-99.4 \%$ similarity to available sequences of the species from Saudi Arabia and Jordan, COI sequences for the rest of the species were not yet available on GenBank, thus representing novel contributions.

The mayflies treated here, like all regional taxa, have differing biogeographical affinities (Table 2). Cloeon vanharteni and Ch. soldani are mainly distributed in the Arabian Peninsula, and their presence in Israel and the Palestinian Authority extends their known distribution limit north-westwards. They most likely will be found in additional aquatic habitats in the Arabian Peninsula and Jordan, and perhaps even further west. They are without a doubt adapted to desert conditions, and appear to be salinity-tolerant in particular, as the salinity levels where these two species have been collected can reach very high values (e.g., 52,700 $\mu \mathrm{S}$ in Milha Stream, $>18,000$ $\mu \mathrm{S}$ in Zin Stream, 13,000 $\mu \mathrm{S}$ in Boqeq Stream; values measured in field at the time of specimen collection). Extreme conditions were also recorded in newly formed aquatic habitats in sinkholes near the Dead Sea, which were colonized by $C$. vanharteni nymphs in several occasions (Hirshberg and Ben-Ami 2019). The remaining two species, $O$. orontensis and $P$. oronti, are endemic

Table 2. New occurrence data of the four mayflies in study area and elsewhere.

\begin{tabular}{lccl}
\hline Species & Israel & Palestinian Authority & Further distribution \\
\hline Cloeon vanharteni & + & + & Jordan (Alhejoj et al. 2020), UAE (Gattolliat and Sartori 2008) \\
Cheleocloeon soldani & + & + & Jordan (Alhejoj et al. 2020), Saudi Arabia (Salles et al. 2014), UAE (Gattolliat and Sartori 2008) \\
Oligoneuriella orontensis & + & & Lebanon (Koch 1988), Syria (Koch 1988), Turkey (Koch 1980) \\
Prosopistoma oronti & + & & Lebanon (Alouf 1977), Syria (Koch 1988) \\
\hline
\end{tabular}


to the Levant. Their geographical ranges are now pushed southwards to include Israeli habitats similar to those reported from Lebanon and Syria. It is unlikely that the ranges of these species extend further south, as low humidity and high temperatures limit their distribution.

The newly reported species join the known 22 mayfly species in Israel and the Palestinian Authority (Demoulin 1973; Malzacher 1992; Sartori 1992; Yanai et al. 2018). The local fauna can be identified at the generic level based on identification keys provided by Sartori (1992; Heptageniidae), Malzacher (1992; Caenidae), and Yanai et al. (2018; Baetis). Preparations for additional faunal contributions and a complete identification key are currently in progress, with the main remaining gaps found in the Baetidae, where at least four additional species await report and description. The common Cloeon dipterum (Linnaeus, 1761) was previously mentioned from Israel and the Palestinian Authority by Samocha (1972) and others (e.g. Dimentman et al. 1992, and numerous other Hebrew ecological studies, such as Gafny and Gasith 2005; Elron and Gafny 2011). These records relate to the most common mayfly species in the region, which however, is an undescribed species, perhaps even two, whose identity should be clarified soon using new molecular and morphological evidence (J.-L. Gattolliat, S. Rutschmann, unpublished data). Until then, we strongly recommend avoiding the use of "Cloeon dipterum" in publications, and we prefer "Cloeon cf. dipterum" instead. Additional local Cloeon species include C. perkinsi Barnard, 1932 (Yanai et al. in press) and $C$. vanharteni (reported here).

Recent study in the region (e.g. Alhejoj et al. 2020) enables data sharing and is expected to yield further discoveries, benefiting entomologists and freshwater ecologists.

\section{Acknowledgements}

Netta Dorchin is much appreciated for her continuous support. We thank Marion Podolak for the assistance with the molecular lab work. ZY was funded in the study years by the Israel Taxonomy Initiative (ITI) and by a Swiss Government Excellence Scholarship (FCS). A fieldtrip to the study area was funded by the Dr Joachim de Giacomi Fund of the Swiss Academy of Sciences (SCNAT). We want to sincerely thank Inês Corrêa Gonçalves, Paulo Cruz, Roman Godunko, and Pavel Sroka for their valuable comments on the manuscript.

\section{Authors' Contributions}

ZY, MS and JLG collected material in the study area, identified it, and wrote the manuscript.

\section{References}

Alhejoj I, Gattolliat J-L, Sartori M (2020) Contribution to the mayflies (Insecta, Ephemeroptera) of Jordan. Check List 16 (2): 237-242. https://doi.org/10.15560/16.2.237

Alouf NJ (1977) On the presence of the genus Prosopistoma (Ephemeroptera) in Lebanon. Description of $P$. oronti sp. n. and P. phoenicium sp. n. Annales de Limnologie 13: 133-139.

Barnard KH (1932) South African may-flies (Ephemeroptera). Transactions of the Royal Society of South Africa 20: 201-259.

Bauernfeind E, Soldán T (2012) The mayflies of Europe (Ephemeroptera). Apollo, Ollerup, 781 pp. https://doi.org/10.1163/978900426 0887

Bojková J, Soldán T (2015) Two new species of the genus Prosopistoma (Ephemeroptera: Prosopistomatidae) from Iraq and Algeria. Zootaxa 4018: 109-123. https://doi.org/10.11646/zootaxa.4018.1.6

Degani G, Herbst GN, Ortal R, Bromley HJ, Levanon D, Glazman H, Regev Y (1992) Faunal relationships to abiotic factors along the River Dan in northern Israel. Hydrobiologia 246: 69-82. https:// doi.org/10.1007/BF00005623

Demoulin G (1973) Contribution à l'étude des éphéméroptères d'Israel. Introduction et I. Heptageniidae. Bulletin de l'Institut Royal des Sciences Naturelles de Belgique 49: 1-19.

Dimentman C, Bromley HJ, Por FD (1992) Lake Hula-reconstruction of the fauna and hydrobiology of a lost lake. The Israel Academy of Sciences and Humanities, Jerusalem, 170 pp.

Elron E, Gafny S (2011) Winter pools (ephemeral ponds) survey in the central and southern coastal plain, March-June 2010. Bactochem and Israel Nature and Parks Authority, 243 pp. [in Hebrew].

Folmer O, Black M, Hoeh W, Lutz R, Vrijenhoek R (1994) DNA primers for amplification of mitochondrial cytochrome $c$ oxidase subunit I from diverse metazoan invertebrates. Molecular Marine Biology and Biotechnology 3: 294-299.

Gafny S, Gasith A (2005) Winter ponds in Israel, survey 1997-2003. Report submitted to Israel Nature and Parks Authority, Tel Aviv, 272 pp. [in Hebrew].

Gattolliat J-L, Sartori M (2008) Order Ephemeroptera. Arthropod Fauna of the UAE 1: 47-83.

Hirshberg O, Ben-Ami F (2019) Sinkholes as a source of life in the Dead Sea region. Aquatic Sciences 81:14: 1-14. https://doi. org/10.1007/s00027-018-0611-2

Imhoff L (1852) Oligoneuria rhenana. Bericht über die Verhandlungen der Naturforschenden Gesellschaft in Basel 10: 177-180.

Kluge NJ, Novikova EA (1992) Revision of Palearctic genera and subgenera of Mayflies in the subfamily Cloeoninae (Ephemeroptera, Baetidae) with description of new species from the USSR. Entomological Review 71: 29-54

Koch S (1980) Beschreibung der Larve von Oligoneuriella orontensis n. sp. aus dem Vorderen Orient und Vergleich mit den paläarktischen Arten von Oligoneuriella Ulmer (Ephemeroptera). Entomologische Zeitschrift 90: 153-160.

Koch S (1988) Mayflies of the northern Levant (Insecta: Ephemeroptera). Zoology in the Middle East 2: 89-112. https://doi.org/10.108 0/09397140.1988.10637565

Kumar S, Stecher G, Tamura K (2015) MEGA7: Molecular Evolutionary Genetics Analysis version 7.0 for bigger datasets. Molecular Biology and Evolution 33: 1870-1874. https://doi.org/10.1093/ molbev/msw054

Linnaeus C (1761) Fauna Svecica sistens Animalia Sveciae regni: mammalia, aves, amphibia, pisces, insect, vermes. Distributa per classes \& ordines, genera \& species, cum differentiis specierum, synonymis auctorum, nominibus incolarum, locis natalium, descriptionibus insectorum. Editio altera, auctior. Stockholmiae: Sumtu \& Literis Direct. Laurentii Salvii. https://oi.org/10.5962/ bhl. title. 46380

Malzacher P (1992) Mayflies from Israel (Insecta, Ephemeroptera) II. - Caenidae. Mitteilungen der Schweizerischen Entomologischen Gesellschaft - Bulletin de la Société Entomologique Suisse 65: 385-394.

Por DF, Bromley HJ, Dimentman C, Herbst GN, Ortal R (1986) River Dan, headwater of the Jordan, an aquatic oasis of the Middle East. Hydrobiologia 134: 121-140. https://doi.org/10.1007/BF00006736 
Salles FF, Gattolliat J-L, Angeli KB, De-Souza MR, Gonçalves IC, Nessimian JL, Sartori M (2014) Discovery of an alien species of mayfly in South America (Ephemeroptera). ZooKeys 399: 1-16. https://doi.org/10.3897/zookeys.399.6680

Samocha M (1972) Ephemeroptera of Israel. MSc thesis, Tel Aviv University, Tel Aviv, $111 \mathrm{pp}$.

Sartori M (1992) Mayflies from Israel (Insecta; Ephemeroptera) I. Heptageniidae, Ephemerellidae, Leptophlebiidae \& Palingeniidae. Revue Suisse de Zoologie 99: 835-858.

Soldán T, Thomas AGB (1983) New and little-known species of mayflies (Ephemeroptera) from Algeria. Acta Entomologica Bohemoslovaca 80: 356-376.

Thomas AGB, Dia A, Moubayed Z (1988) Additions and corrections to the Ephemeroptera fauna of the Near East: 1. Prosopistoma phoeni- cium Alouf, $1977=$ P. oroni Alouf, 1977 nov. syn. (Ephemeroptera) Bulletin de la Société d'Histoire Naturelle de Toulouse 124: 23.

Yanai Z, Gattolliat J-L, Dorchin N (2018) Taxonomy of Baetis Leach in Israel (Ephemeroptera, Baetidae). ZooKeys 794: 45-84. https:// doi.org/10.3897/zookeys.794.28214

Yanai Z, Sartori M, Dor R, Dorchin N (2017) Molecular phylogeny and morphological analysis resolve a long-standing controversy over generic concepts in Ecdyonurinae mayflies (Ephemeroptera: Heptageniidae). Systematic Entomology 42: 182-193. https://oi. org/10.1111/syen.12203

Yanai Z, Graf W, Terefe Y, Sartori M, Gattolliat J-L (in press) Re-description and range extension of the Afrotropical mayfly Cloeon perkinsi (Ephemeroptera, Baetidae). European Journal of Taxonomy. 